\title{
Patch-Clamp Recordings Reveal Powerful GABAergic Inhibition in Dentate Hilar Neurons
}

\author{
Ivan Soltesz and Istvan Mody \\ Department of Anesthesiology, and Pain Management, UT Southwestern Medical Center, Dallas, Texas 75235-9068
}

\begin{abstract}
Whole-cell and cell-attached patch-clamp recordings were used to investigate the nature of GABA receptor-mediated inhibition in the adult rat dentate gyrus in standard $400-\mu \mathrm{m}$ thick horizontal slices. In the presence of the glutamate receptor antagonists D-2-amino-5-phosphonovaleric acid and 6-cyano-7-nitroquinoxaline-2,3-dione, whole-cell voltageclamp experiments with chloride-filled electrodes $\left([\mathrm{Cl}]_{\text {in }}=\right.$ $\left.\left[\mathrm{Cl}^{-}\right]_{\text {out }}\right)$ revealed a high degree of spontaneous activity $(10-$ $60 \mathrm{~Hz}$ ) in all hilar neurons (HNs) recorded with access resistances lower than $20 \mathrm{M} \Omega$. The events were inward at negative holding potentials, reversed at around the $\mathrm{Cl}^{-}$equilibrium potential, and were completely abolished by the specific antagonists of the GABA $_{A}$ receptor channel picrotoxin and SR-95531 in a reversible manner, indicating that they were spontaneous inhibitory postsynaptic currents (sIPSCs) mediated by GABA $_{A}$ receptors. The majority of the sIPSCs were TTX-insensitive miniature currents resulting from the action potential-independent release of GABA.
\end{abstract}

The 10-90\% rise times and the monoexponential decay time constants of the SIPSCs were significantly longer in HNs than those found in neighboring granule cells (GCs). Furthermore, the decay time constant of the hilar SIPSCs was not voltage dependent, contrary to the voltage dependency of the decay time constant of the sIPSCs recorded from GCs. As HNs have longer electrotonic length than GCs do, dendritic filtering may contribute to the kinetic differences. Nonstationary fluctuation analysis showed that whereas the number of channels open at the peak of individual sIPSCs was similar, the single-channel conductances significantly differed between the two cell groups. The $21 \%$ smaller single-channel conductance and the existence of electrotonically close GABAergic synapses on HNs indicate that dendritic filtering alone cannot explain the differences between HNs and GCs. The distinct subunit composition of the GABA receptor channels in HNs and GCs may also be responsible for the altered kinetics of IPSCs in HNs. However, the subunit specific benzodiazepine agonist zolpidem ( $3 \mu \mathrm{M})$ prolonged the monoexponential decay time constants in both HNs and

\footnotetext{
Received. July 15, 1993; revised Sept. 22, 1993; accepted Oct. 14, 1993.

We thank Dr. J. Dempster for supplying us with the Strathclyde Electrophysiology Software, Dr. Y. De Koninck for writing the analysis programs and for stimulating discussions, and I. Parada for invaluable technical assistance. We also thank Drs. E. Buhl, T. F. Freund, M. Frotscher, C. Ribak, and P. Somogyi for valuable comments on the anatomy of hilar neurons. This work was supported by NINDS Grant NS-30549 to I.M.

Correspondence should be addressed to Department of Anesthesiology and Pain Management, UT Southwestern Medical Center, 5323 Harry Hines Boulevard, Dallas, TX 75235-9068.

Copyright (C) 1994 Society for Neuroscience $0270-6474 / 94 / 142365-12 \$ 05.00 / 0$
}

GCs. Thus, differences between the $\mathrm{GABA}_{\mathrm{A}}$ receptors of the two cell types are not due to a simple all-or-none presence/ absence of the $\alpha 5$ subunit.

In order to determine the effect of the activation of GABA receptors on the resting membrane potential in HNs and GCs in a nonintrusive way, we used single potassium channels as transmembrane voltage sensors by measuring the change in their conductance in cell-attached recordings in response to the $\mathrm{GABA}_{\mathrm{A}}$ agonist muscimol. $\mathrm{GABA}_{\mathrm{A}}$ receptor activation resulted in a strong peak depolarization (about $16 \mathrm{mV}$ ) in GCs but induced only small (about $4 \mathrm{mV}$ ) depolarizations in HNs.

These results reveal for the first time that spontaneous activation of GABA receptors takes place in $\mathrm{HNs}$ with a high frequency. Thus, while significant differences exist in the way GABAergic inhibition operates in the two neighboring neuronal population, it is highly unlikely that a general lack of inhibition can explain the extreme vulnerability of HNs to excitotoxic insults.

[Key words: $\mathrm{GABA}_{\mathrm{A}}$ receptor, granule cell, dentate gyrus, inhibitory postsynaptic current, excitotoxicity, hilus, potassium channel, patch clamp, synchronization]

The hilus of the dentate gyrus is in a strategic position to influence neuronal information processing in corticolimbic networks. Indeed, several prominent EEG rhythms of the hippocampal formation have been described in the hilus, including, among others, the theta oscillations and the fast (" $40 \mathrm{~Hz}$ ") rhythms (Buzsáki et al., 1983; Miller, 1991; Soltesz and Deschênes, 1993). The large variety of electrical behaviors exhibited by the dentate hilus is presumably a reflection of the number of neuronal computations that may take place in it. Some of these rhythms, such as the fast waves, have the highest amplitude in the hilus (Buzsáki et al., 1983; Soltesz and Deschênes, 1993), indicating that hilar neurons (HNs) may be particularly adept at temporal synchronization of their neuronal activities. It has been suggested that synchronization in the hilus may take place via depolarizing $\mathrm{GABA}_{\mathrm{A}}$ receptor-mediated responses (Michelson and Wong, 1991). However, little is known about the physiology of GABAergic synaptic events in HNs. In fact, it has been suggested that the high sensitivity to excitotoxic insults (Mouritzen-Dam, 1980; Sloviter, 1983, 1987, 1989, 1991; Babb et al., 1984; Scharfman and Schwartzkroin, 1990; Sutula et al., 1992) of spiny HNs, of which the mossy cells are the most abundant (Amaral, 1978; Frotscher et al,, 1991), might be connected to the relative absence of GABAergic inhibitory influences (Scharfman, 1991). This hypothesis seemed to have been supported by observations in vitro carried out with sharp microelectrodes in conventional brain slices (Scharfman, 1992; 


\section{Whole-cell}

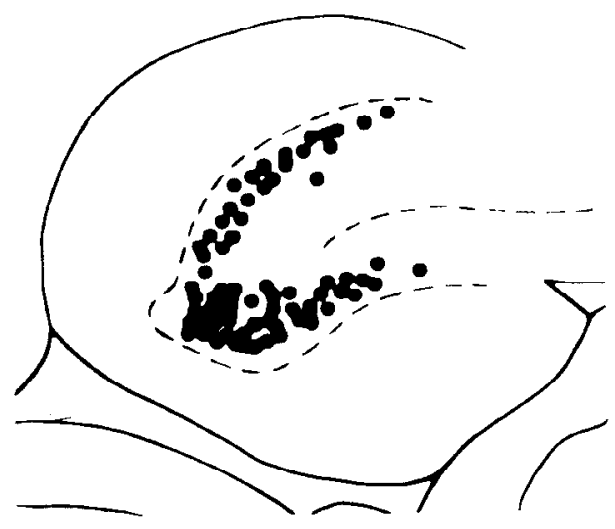

\section{Cell-attached}

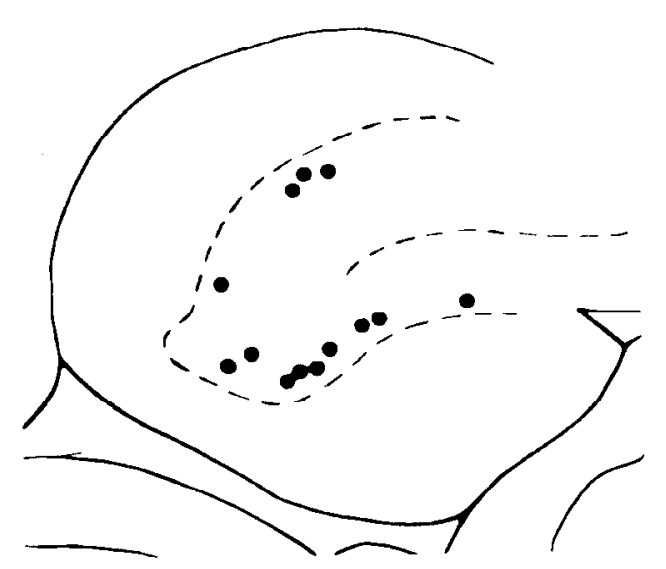

Figure 1. The position of the HNs (solid circles) recorded in the wholecell mode is shown on the top, while those HNs that were recorded in the cell-attached mode are indicated on the bottom schematic drawing of the dentate gyrus [plate 109 of the Paxinos-Watson (1986) atlas]. The dashed lines indicate the border of the GC layer with the hilus and the layer of the CA3c pyramidal cells.

Strowbridge et al., 1992), as well as with whole-cell recordings in thin slices (Livsey and Vicini, 1992), indicating that the blockade of the intense, exclusively depolarizing spontaneous activity in spiny HNs by glutamate receptor antagonists (without 4-aminopyridine) abolishes all spontaneous activity and does not reveal any "hidden," glutamate receptor antagonist-insensitive synaptic events. Even the evoked responses of HNs, recorded in control medium, were reported to be dominated by excitatory potentials whereas small inhibitory responses occurred only in few HNs (Scharfman and Schwartzkroin, 1988; Scharfman, 1991). However, it has been known from anatomical studies that GABAergic terminals are abundant in the hilus and are present on HNs (Ribak et al., 1978, 1985; Ribak and Seress, 1988; Han et al., 1993). This contrasts sharply with the lack of electrophysiological evidence for prominent inhibitory spontaneous or evoked activity.

Recently, however, two reports indicated that HNs may be under more effective inhibitory control than previously thought. First, a recent in vitro sharp electrode study (Scharfman, 1992) reported that spiny HNs responded with IPSPs to high- but not to low-intensity electrical stimulation, in the presence of $\mathrm{D}-2$ amino-5-phosphonovaleric acid (AP5) and 6-cyano-7-nitroquinoxaline-2,3-dione (CNQX), although no spontancous inhibitory activity was seen. Second, mossy cells responded with prominent IPSPs to stimulation of the entorhinal cortex in vivo (Soltesz et al., 1993). Furthermore, in the same in vivo study the intracellular theta rhythm of mossy cells showed strong voltage dependency in its phase with respect to the EEG theta rhythm, a property shared with $\mathrm{CA} 3$ and CA1 neurons thought to indicate the involvement of fast, $\mathrm{Cl}^{-}$-dependent, $\mathrm{GABA}_{\mathrm{A}}$ receptor-mediated IPSPs (Artemenko, 1972; Leung and Yim, 1986; Fox, 1989; Soltesz and Deschênes, 1993). We have undertaken the present study to seek answers to the following questions. (1) Could spontaneous inhibitory activity, mediated by $\mathrm{GABA}_{\mathrm{A}}$ receptors, be revealed in HNs? (2) If yes, what differences do the spontaneous events show with respect to the well-studied spontaneous postsynaptic currents (sIPSCs) of the neighboring granule cells (GCs)? (3) Is the action of $\mathrm{GABA}_{\mathrm{A}}$ receptor activation depolarizing or hyperpolarizing in HNs and GCs? The answers to these questions are important because they advance our knowledge of how inhibition operates in corticolimbic systems with consequences for the understanding of the neuronal mechanisms underlying learning and memory as well as several pathological states.

Some of the results have been presented in abstract form (Soltesz and Mody, 1993).

\section{Materials and Methods}

Slice preparation. The preparation of slices was done as described before (Otis et al., 1991; Staley and Mody, 1991). Briefly, adult (60-120 d old, $250-350 \mathrm{gm}$ ) male Wistar rats were decapitated under pentobarbital sodium anesthesia $(75 \mathrm{mg} / \mathrm{kg}$, i.p.) and the brains removed. The brain was cooled in $4^{\circ} \mathrm{C}$ artificial cerebrospinal fluid (ACSF), composed of (in mM) $126 \mathrm{NaCl}, 2.5 \mathrm{KCl}, 26 \mathrm{NaHCO}_{3}, 2 \mathrm{CaCl}_{2}, 2 \mathrm{MgCl}_{2}, 1.25 \mathrm{NaH}_{2} \mathrm{PO}_{4}$, and 10 glucose. Horizontal whole brain slices (Lambert and Jones, 1990; Staley and Mody, 1991) (400 $\mu$ m thick) were prepared using a vibratome tissue sectioner (Lancer series 1000). The brain slices were sagittally bisected onto two hemispheric components and incubated submerged in a storage chamber at $32^{\circ} \mathrm{C}$.

Electrodes and solutions. Both whole-cell and cell-attached recordings were obtained from HNs (the recording sites are shown separately for the two types of recordings in Fig. 1) and from GCs. Patch electrodes were pulled from borosilicate (KG-33) glass capillary tubing $(1.5 \mathrm{~mm}$ o.d.; Garner Glass) using a Narishige PP-83 two-stage electrode puller. Tip dimensions were $0.5-1.0 \mu \mathrm{m}$ i.d. and $3-4 \mu \mathrm{m}$ o.d., with the cellattached electrodes being slightly smaller. Only the electrodes used for cell-attached recordings were fire polished and coatings were not used.

Intracellular or, in the case of the pipettes used for cell-attached recordings, intrapipette solutions were composed of (in $\mathrm{mM}$ ) 135 either potassium or cesium chloride or in a few experiments cesium gluconate, $2 \mathrm{MgCl}_{2}$, and $10 \mathrm{~N}$-2-hydroxyethylpiperazine- $\mathrm{N}$-2-ethanesulfonic acid (HEPES); the solution was buffered with $\mathrm{CsOH}$ or $\mathrm{KOH}$ to $\mathrm{pH} 7.2$ in high-performance liquid chromatography (HPLC) grade water (Omnisolve, EM Science, Gibbstown, NJ). No calcium buffer was used. Wholecell voltage-clamp recordings were done with $10 \mathrm{mM}$ QX-314 (Alamone Labs.), cell-attached recordings with $2 \mathrm{~mm} \mathrm{CaCl}_{2}$ in the pipette. Final osmolarity for all solutions was 260-280 mOsm. All salts were obtained from Fluka.

Recordings and analysis. The application of the whole-cell recording technique to the standard brain slice preparation has been described in detail (Blanton et al., 1989; Staley et al., 1992). Recordings were obtained with an Axopatch-200A amplifier (Axon Instruments) (in the case of the few cells that were recorded in the current-clamp mode, an Axoclamp $2 \mathrm{~A}$ amplifier was used), digitized at $88 \mathrm{kHz}$ (Neurocorder, NeuroData) before being stored in PCM form on videotape, and filtered DC to $1-3 \mathrm{kHz}$ (eight-pole Bessel) before digitization by the computer for analysis that was performed with the Strathclyde Electrophysiology Software (courtesy of J. Dempster, Univ. of Strathclyde, UK). In the 

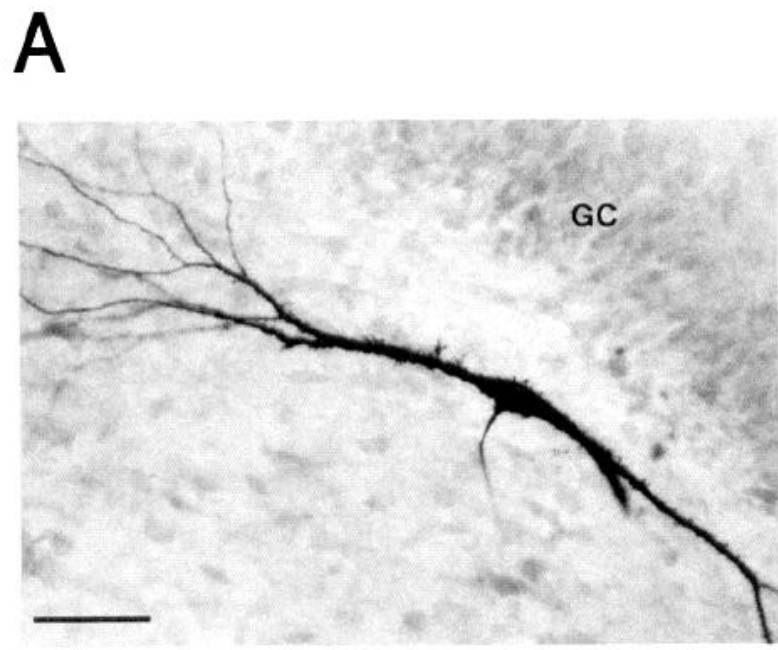

B
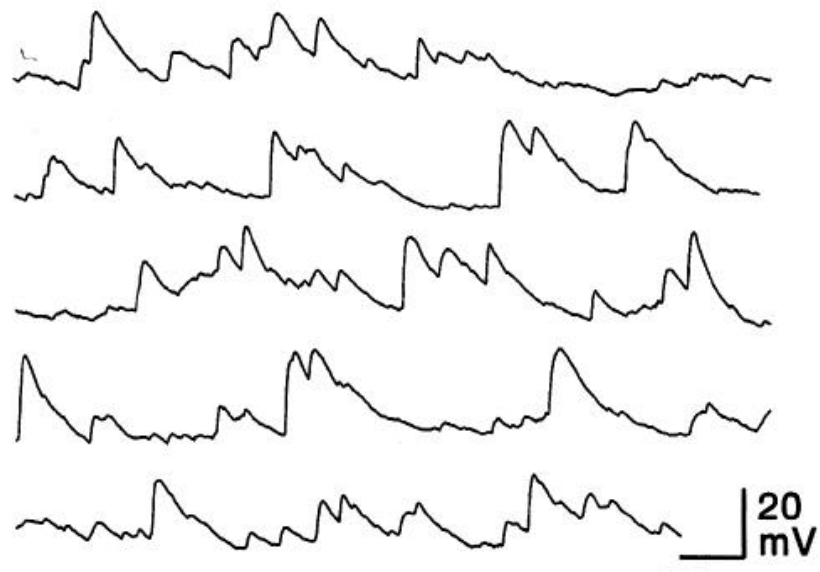

$50 \mathrm{~ms}$

Figure 2. HNs show intense depolarizing activity in control medium in current clamp. $A$, Photomicrograph of the cell whose activity is shown in $B$. Note the prominent spines on the cell body and on the proximal dendrite. The cell had a single dendrite in the molecular layer. The position of the cell; the large cell body; the presence of numerous large, complex spines on the soma and proximal dendrites; and small, simple ones on the distal dendrites and the single dendrite in the molecular layer suggest that this cell is a hilar mossy cell. $B$, Whole-cell currentclamp recording (Cs-gluconate electrode) shows the intense depolarizing activity characteristic of spiny HNs. The cell was at RMP. The individual traces are consecutive records. Scale bar in $A, 50 \mu \mathrm{m}$.

case of the cell-attached recordings, the channel activity was also recorded with a patch-clamp amplifier (Axopatch 200A) (low-pass filtered $\mathrm{DC}$ to $10 \mathrm{kHz}$ ) in pulse code modulated (PCM) form onto videotapes. Channel data were redigitized at $3 \mathrm{kHz}$, low-pass filtered at $500 \mathrm{~Hz}(-3$ $\mathrm{dB}$, eight-pole Bessel), and analyzed off line with the single-channel analysis program of the Strathclyde Electrophysiology Software using a $50 \%$ threshold-crossing event detection algorithm.

Constant-current stimuli (50-200 $\mu \mathrm{sec})$ were applied from a bipolar $90 \mu \mathrm{m}$ tungsten stimulating electrode placed in the molecular layer of the dentate gyrus. With the exception of the current-clamp experiments, which were done in control ACSF, recordings were performed in ACSF containing (in $\mu \mathrm{M}$ ) $25 \mathrm{D}$-2-amino-5-phosphonovaleric acid (AP5; Cambridge Research Biochemicals) and 10 6-cyano-7-nitroquinoxaline-2,3dione (CNQX; Tocris Neuramin).

Nonstationary noise analysis was performed as described elsewhere (Sigworth, 1980; Robinson et al., 1991; Traynelis et al., 1991, 1993; De Koninck et al., 1992). Briefly, multiple, overlapping events were re-
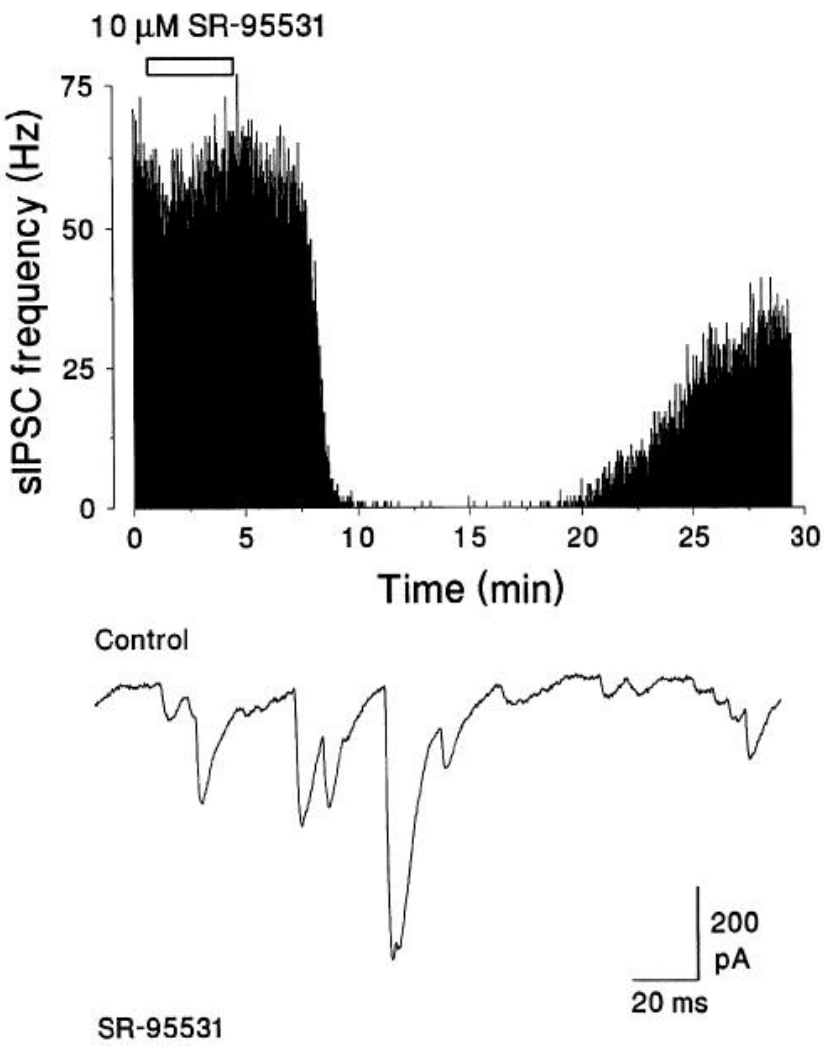

Figure 3. The sIPSCs are $\mathrm{GABA}_{\mathrm{A}}$ receptor-mediated events. The effect of the $\mathrm{GABA}_{A}$ receptor antagonist SR-95531 on the frequency of the sIPSCs recorded with whole-cell patch pipettes in voltage clamp is shown, in the presence of AP5 and CNQX. Traces from control (Control) and the drug-effected state $(S R-95531)$ are presented below. Note that the $\mathrm{GABA}_{\mathrm{A}}$ receptor antagonist abolished all activity.

jected, and then the individual events were selected on the basis of their rise times and decay time constants (only those that were close to the mean of all events were analyzed further) in order to be able to deal with a fairly homogeneous population. About 100-200 sIPSCs were used in each cell. The ensemble average current was scaled to the peak of each event and the latter was divided into bins of equal amplitudes on the current scale to calculate the variance versus mean amplitude of the current during the decay phase of the sIPSCs (within a time window of fixed length). Within each bin the variance of the current $\left(\sigma^{2}\right)$ around the scaled average was computed and the baseline variance was then subtracted. The following parabola (Sigworth, 1981) was fitted (leastsquare simplex method) through the points of the variance versus mean current relationship:

$$
\sigma^{2}=i I_{m}-I_{m}{ }^{2} / N
$$

where $I_{m}$ is the measured current, $i$ is the unitary current, and $N$ is the number of open channels at the peak of the sIPSC.

The electrotonic length of the membrane $\left(L_{\mathrm{vc} 2}\right.$, according to the notations of Holmes and Rall, 1992) was estimated in voltage-clamp recordings by analyzing current transients following 5-10 mV, 100-mseclong voltage pulses (Rall, 1969; Holmes and Rall, 1992; Jackson, 1992), according to the equation (Rall, 1969)

$$
L_{\mathrm{vc} 2}=(\pi / 2)\left(9 \tau_{\mathrm{vc} 2}-\tau_{\mathrm{vc1}}\right)^{1 / 2}\left(\tau_{\mathrm{vc} 1}-\tau_{\mathrm{vc} 2}\right)^{-1 / 2},
$$

where $\tau_{\mathrm{vc} 1}$ and $\tau_{\mathrm{vc} 2}$ are the slow and fast time constants, respectively, of the current transients. According to simulations performed by Holmes and Rall (1992), this method overestimates the real electrotonic length $(L)$ of the membrane particularly if there is a severe tapering in the diameter of distal dendrites.

Drugs were applied by bath perfusion. The bath concentrations were (in $\mu_{\mathrm{M}}$ ) 100 picrotoxin (Sigma), $10 \mathrm{SR}-95531$ (Cambridge Research Biochemicals), 100 muscimol (Fluka), 3 or 30 zolpidem (courtesy of 
Figure 4. The effect of TTX on the sIPSCs of an HN. Top traces show the sIPSCs in CNQX/AP5-containing (control) medium and in the presence of TTX. Middle traces show the blocking effect of TTX on the IPSCs evoked by electrical stimulation of the molecular layer. Lower panels show the interevent histograms of the sIPSCs in control medium (left) and in TTX (right) binned on a log scale. Note that TTX abolished the evoked response while it did not cause any change in the mean interevent interval and thus in the mean frequency or amplitude (not shown) of the spontaneous events.
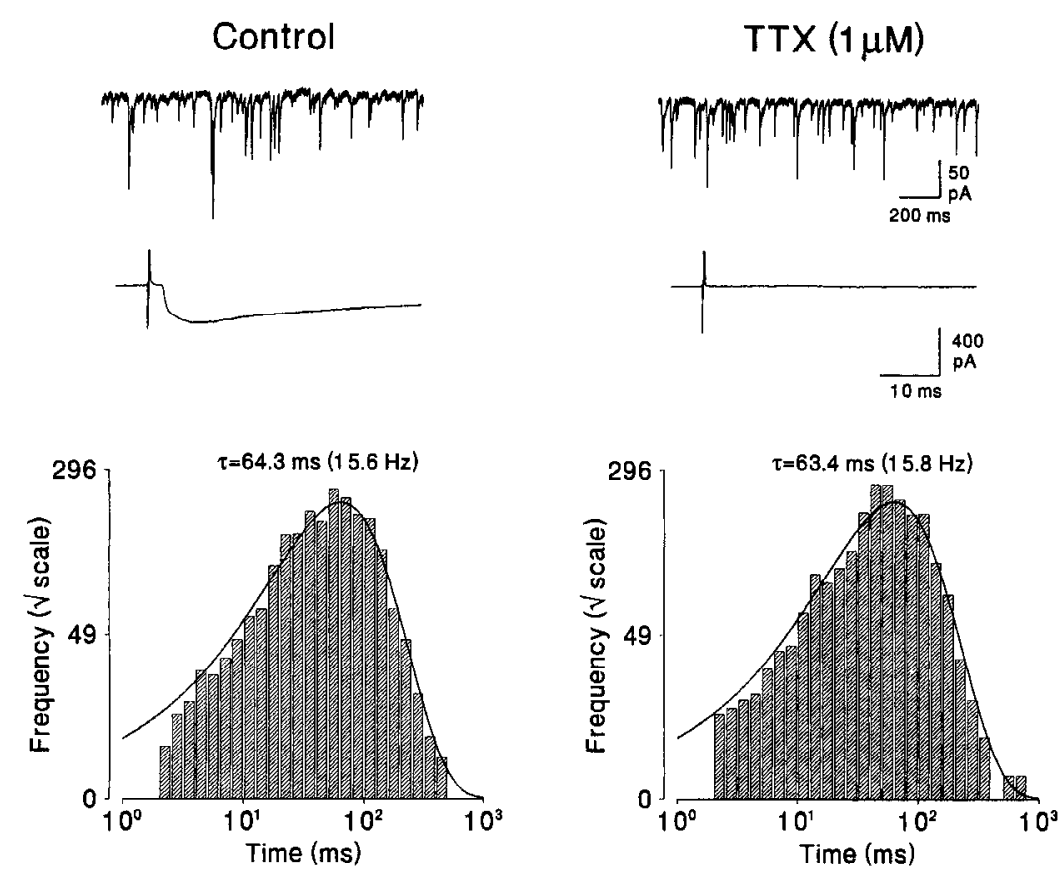

Dr. G. White, Neurogen Corp.), and 1 tetrodotoxin (TTX; Calbiochem). In some experiments biocytin (0.5\%, Sigma) was included in the pipette and after the end of the recording the slice was allowed to stay in the chamber for an additional 10-15 min and then it was placed between filter papers and put into a fixative solution containing $4 \%$ paraformaldehyde. The slices were resectioned with a freezing microtome and processed for biocytin immunocytochemistry according to the protocol described by Horikawa and Armstrong (1988). Statistical analyses were performed using spss for Windows with a level of significance of 0.05 . Data are presented as mean \pm SE ( $n=$ number of cells).

\section{Results}

Whole-cell voltage clamp reveals sIPSCs in HNs

In HNs of the rat dentate gyrus intense excitatory synaptic activity can be observed in control medium both with sharp electrode (Scharfman and Schwartzkroin, 1988; Scharfman, 1991; Strowbridge et al., 1992) and with whole-cell voltage-clamp (Livsey and Vicini, 1992) as well as current-clamp recordings (Fig. 2). Six HNs were injected with biocytin, and all of them proved to be similar to that shown in Figure $2 A$; that is, they all had large cell bodies, prominent spines on their somata and proximal dendrites, and smaller spines on their distal dendrites. As the most abundant deep HNs are spiny, like the mossy cells with large cell bodies (Amaral, 1978; Scharfman and Schwartzkroin, 1988; Frotscher et al., 1991), the chance of recording from this cell type is large.

Contrary to what has been reported before, whole-cell voltageclamp experiments (with symmetrical chloride, i.e., $\left[\mathrm{Cl}^{-}\right]_{\text {in }}=$ $\left[\mathrm{Cl}^{-}\right]_{\text {out }}$ ) revealed a high degree of spontaneous synaptic activity even in the presence of the glutamate antagonists AP5 $(25 \mu \mathrm{M})$ and CNQX $(10 \mu \mathrm{M})$ at frequencies of $10-65 \mathrm{~Hz}$ (e.g., Fig. 3) in all HNs recorded with access resistances lower than $20 \mathrm{M} \Omega$. The events were inward currents at negative holding potentials (Figs. $3,4,5 B$; see Fig. $7 A)$ and they reversed at around $0 \mathrm{mV}(2.43$ $\mathrm{mV})$. The $\mathrm{GABA}_{\mathrm{A}}$ receptor antagonists picrotoxin $(100 \mu \mathrm{M} ; n$ $=2)$ and SR-95531 $(10 \mu \mathrm{M} ; n=5)$ reversibly abolished all activity (e.g., Fig. 3), and thus the events recorded in the presence of AP5 and CNQX were spontaneous inhibitory postsynaptic currents (sIPSCs) mediated by $\mathrm{GABA}_{\mathrm{A}}$ receptors. TTX $(1 \mu \mathrm{M})$, an antagonist of voltage-dependent sodium channels, slightly reduced the frequency of the sIPSCs by $-17.7 \pm 14.7 \%(n=$ 6) (Fig. 4), a value that is considerably smaller than what has been reported for GCs, where approximately $50 \%$ of the sIPSCs are TTX sensitive (Otis et al., 1991). This showed that the majority of the sIPSCs in HNs were generated by action potential-independent release of GABA; that is, they were miniature synaptic currents.

\section{Electrophysiological characteristics of SIPSCS}

As demonstrated in the examples of GC and HN sIPSCs in Figure 5, $A$ and $B$, sIPSCs in HNs were slower rising and slower decaying than sIPSCs from GCs. We took great care to ascertain that these kinetic differences were not due to differences in access resistances. Thus, we selected eight HNs and five GCs that were recorded with similarly low access resistances (5.5-7.5 M $)$. Two hundred sIPSCs were studied in each cell immediately after switching off the test pulse used to check the access resistance. As Figure 6 shows, in spite of the similar access resistances, the kinetic differences were unequivocal, even though in this group of cells the amplitude of the sIPSCs was similar. Analysis of the sIPSCs in a larger population of neurons revealed that the rise times $(0.59 \pm 0.06 \mathrm{msec} ; n=17)$ and decay time constants $(4.65 \pm 0.29 \mathrm{msec} ; n=17)$ in HNs were significantly $(p<0.05$, two-tailed $t$ test) higher than those found in neighboring GCs (0.32 $0.04 \mathrm{msec}$ and $3.66 \pm 0.29 \mathrm{msec}$, respectively; $n=9$ ). Although the average amplitude of the sIPSCs of $\mathrm{HNs}$ was smaller than that of the sIPSCs from GCs (recorded at -60 to $-65 \mathrm{mV}$ holding potentials; HNs, $-83.8 \pm 7.82 \mathrm{pA}$; GCs, $-118.65 \pm$ $22.33 \mathrm{pA}$ ), the difference did not reach a statistically significant level. The slow rise times of hilar sIPSCs did not result from multiple overlapping events, since no inflection point was present on the rising phase of the analyzed sIPSCs (e.g., Fig. $5 C, D$ ). In addition to the differences between the rise times and the decay time constants, a difference was noted between the voltage 
A

Granule Cell

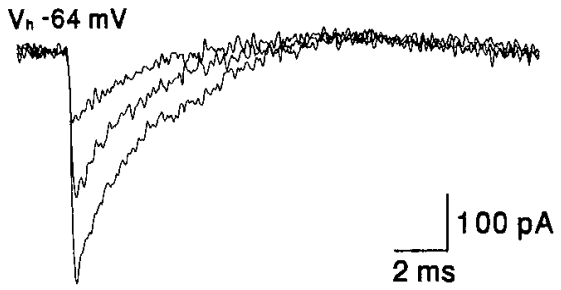

C

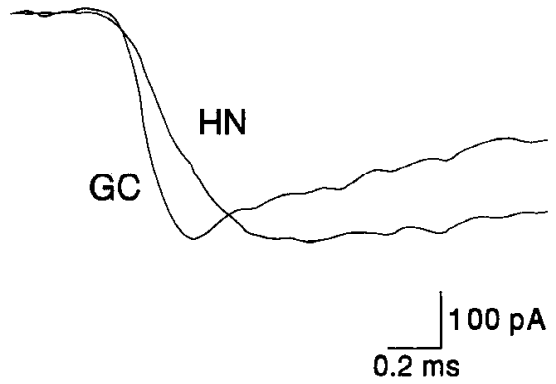

Hilar Neuron
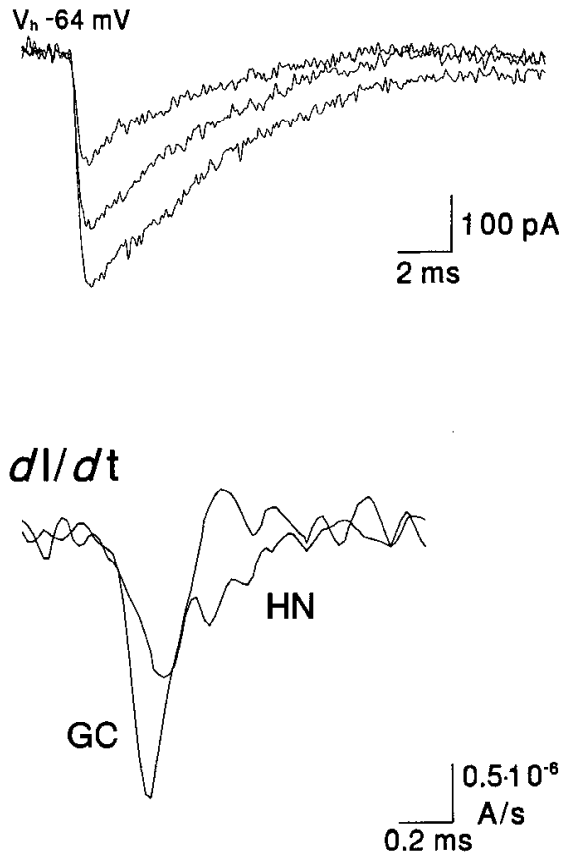

Figure 5. The sIPSCs of GCs and HNs. $A$ and $B$, The sIPSCs of the GC $(A)$ appear faster rising and faster decaying than those recorded from the HN $(B)$. $C$ and $D$, The slower rise time of the $\mathrm{HN}$ is not due to the temporal summation of sIPSCs, since there is no inflection point (i.e., no "notch" can be seen above the baseline noise) on the rising phase of the synaptic currents. dependencies of the decay time constants of the sIPSCs recorded from HNs and GCs. Hilar sIPSCs were not statistically different at +25 and $-75 \mathrm{mV}$ even when the access resistances were the same at these two membrane potentials $(n=4)$. This property of the hilar sIPSCs contrasts sharply with the voltage dependency of the decay time constant of sIPSCs recorded from GCs, where a $132 \mathrm{mV}$ change in membrane potential produces an $e$-fold prolongation (Otis and Mody, 1992).

The anatomical structure and size of $\mathrm{HNs}$ and GCs are rather different, indicating that the electrotonic cable structure might also differ (Rall, 1969; Holmes and Rall, 1992; Jackson, 1992; Livsey and Vicini, 1992; Spruston and Johnston, 1992; Staley et al., 1992), which, in turn, might cause kinetic differences in the sIPSCs. Indeed, previously published whole-cell studies of GCs and HNs reported a difference in the electrotonic length $(L)$ between the two cell groups (Livsey and Vicini, 1992; Staley et al., 1992). In order to confirm the existence of such a difference between the GCs and HNs in our sample, we performed an analysis of the electrotonic properties according to the method
A
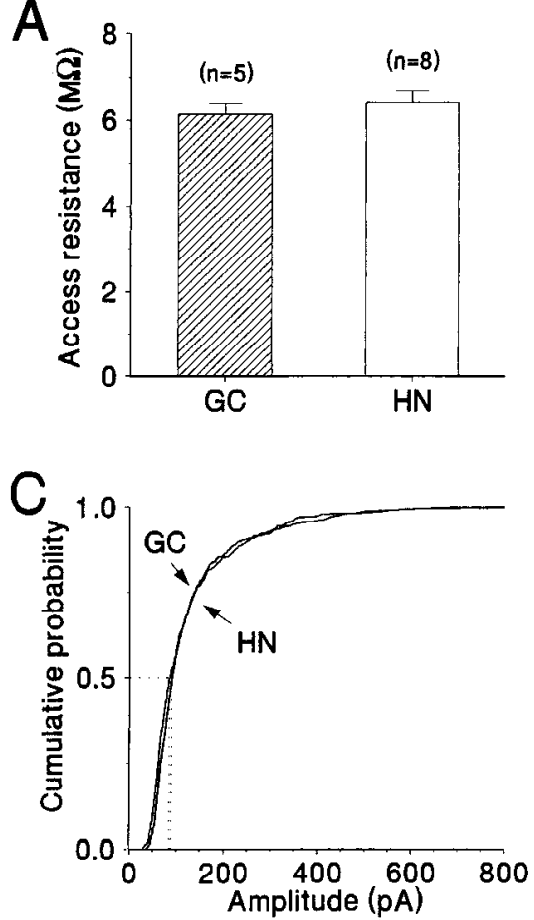
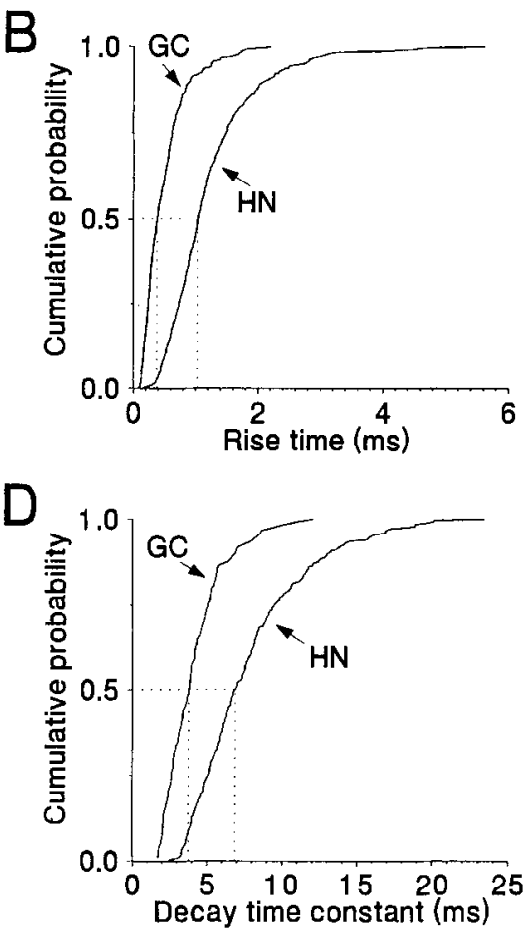

Figure 6. The sIPSCs of HNs have slower rise times and decay time constants than GCs do. $A$, A group of cells consisting of five GCs and eight HNs were selected on the basis that they were recorded with similarly low access resistances. Two hundred sIPSCs were collected from each cell immediately after switching off the test pulse used to check the access resistance (series resistance compensation, $>70 \%$ ). These IPSCs were pooled ( $n=1000$ for GCs; $n=1600$ for HNs) and the plots in $B-$ $D$ refer to data from these pooled events. $B-D$, Cumulative probability plots show that in these selected IPSCs recorded with similar access resistances, the 10$90 \%$ rise times were significantly slower and decay time constants longer in $\mathrm{HNs}$ than in GCs, even though their amplitudes/conductances did not differ. 


\section{A Granule Cell}
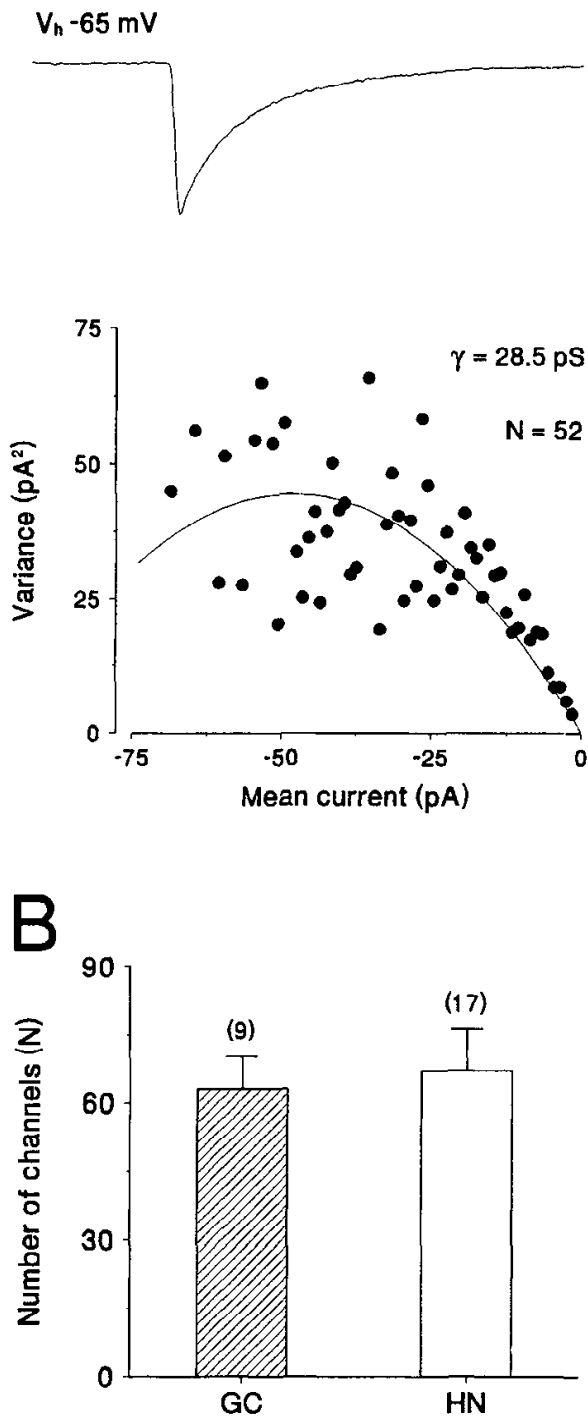

Hilar Neuron
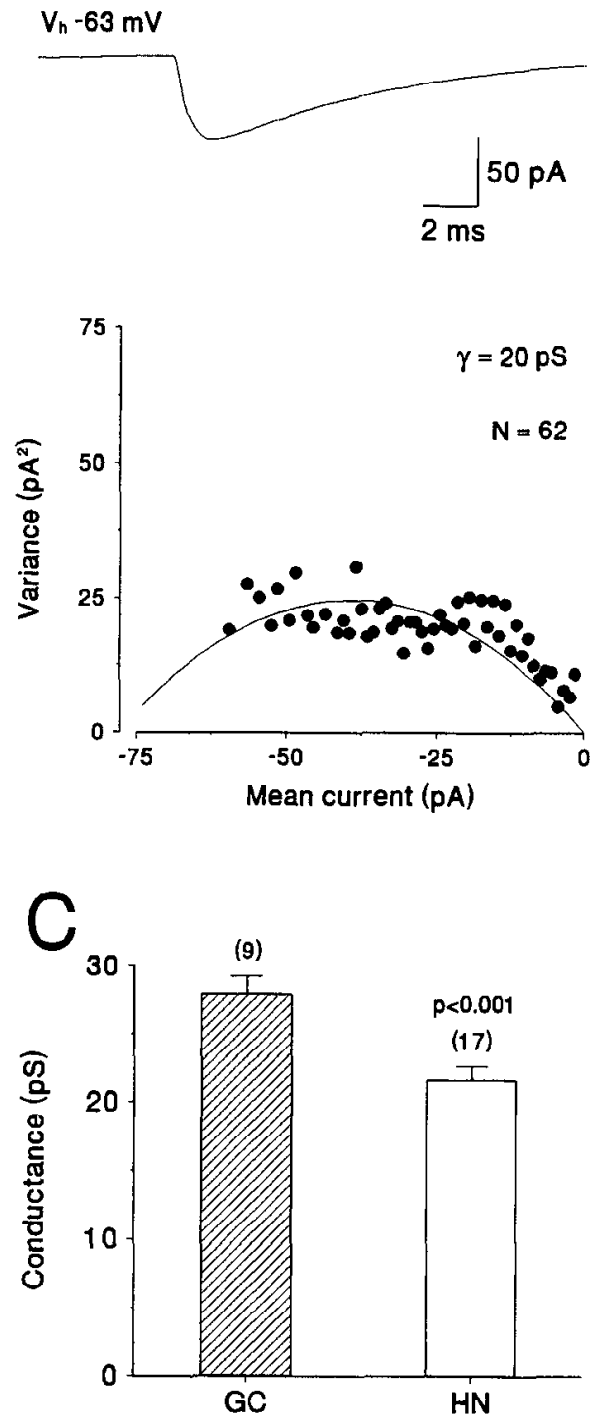

Figure 7. Nonstationary fluctuation (noise) analysis of sIPSCs in GCs and HNs. $A$, An example of the averaged sIPSCs and the mean current versus variance plots in a representative $\mathrm{GC}$ and an $\mathrm{HN}$. $B$ and $C$, Fluctuation analysis performed on sIPSCs from nine GCs and $17 \mathrm{HNs}$ revealed that while the number of subsynaptic channels are similar, the single-channel conductance of the $\mathrm{GABA}_{\mathrm{A}}$ channel of HNs is significantly smaller than that of GCs. of Jackson (1992) in two HNs and two GCs that were recorded with similarly low access resistances (6-9 M $\Omega$ ). The analysis showed that HNs had longer $L_{\mathrm{vc2}}$ values (1.84 and 1.69 in HNs vs 0.89 and 0.33 in GCs) [the sIPSC characteristics in these cells followed the general trend reported above (130-250 events): rise time, $0.72 \pm 0.42$ and $0.24 \pm 0.05 \mathrm{msec}$ in HNs vs $0.17 \pm 0.08$ and $0.23 \pm 0.08 \mathrm{msec}$ in GCs; decay time constant, $5.38 \pm 1.38$ and $5.69 \pm 1.42 \mathrm{msec}$ in HNs vs $4.52 \pm 1.26$ and $5.57 \pm 1.62$ msec in GCs]. The about twice-long $L_{\mathrm{vc} 2}$ of HNs suggests that the slower kinetic properties of the hilar sIPSCs might be due to dendritic filtering. In a similar manner to that reported by Livsey and Vicini (1992) for sEPSCs of HNs, in four cells (100200 sIPSCs each) we found no correlation between the rise times and the decay time constants of hilar sIPSCs $(r=0.09 \pm 0.01$; range, $0.07-0.13)$ and in $17 \mathrm{HNs}$ there was no correlation $(r=$ 0.47 ) between the rise times versus decay time constants of averaged sIPSCs. It should be noted, however, that the lack of correlation between rise times and decay time constants does not necessarily indicate that electrotonic filtering is an unlikely cause of kinetic differences (Major, 1993; Spruston et al., 1993; Traynelis et al., 1993).

The nature of the subsynaptic channels underlying the sIPSCs

Recent in situ hybridization studies indicated differences between the subunit composition of $\mathrm{GABA}_{\mathrm{A}}$ receptors of $\mathrm{HNs}$ and GCs (Persohn et al., 1992; Wisden et al., 1992). Different subunit composition may result in different channel kinetics. In order to determine the single-channel conductance and number of hilar and granular $\mathrm{GABA}_{\mathrm{A}}$ channels, we applied the nonstationary noise analysis technique (Sigworth, 1980; Robinson et al., 1991; Traynelis et al., 1991; De Koninck et al., 1992). This method showed a significant difference between the single-channel conductance of the $\mathrm{GABA}_{\mathrm{A}}$ channels present on these two neuronal populations (HNs, $21.6 \pm 0.98 \mathrm{pS}$; GCs, $27.9 \pm 1.35$ pS) (Fig. 7). However, the number of subsynaptic channels open at the peak of sIPSCs were similar (HNs, $67 \pm 9$; GCs, $63 \pm$ 7) (Fig. 7). Although the single-channel conductance calculated by this method can be influenced by dendritic filtering (see Dis- 


\section{Granule Cell}
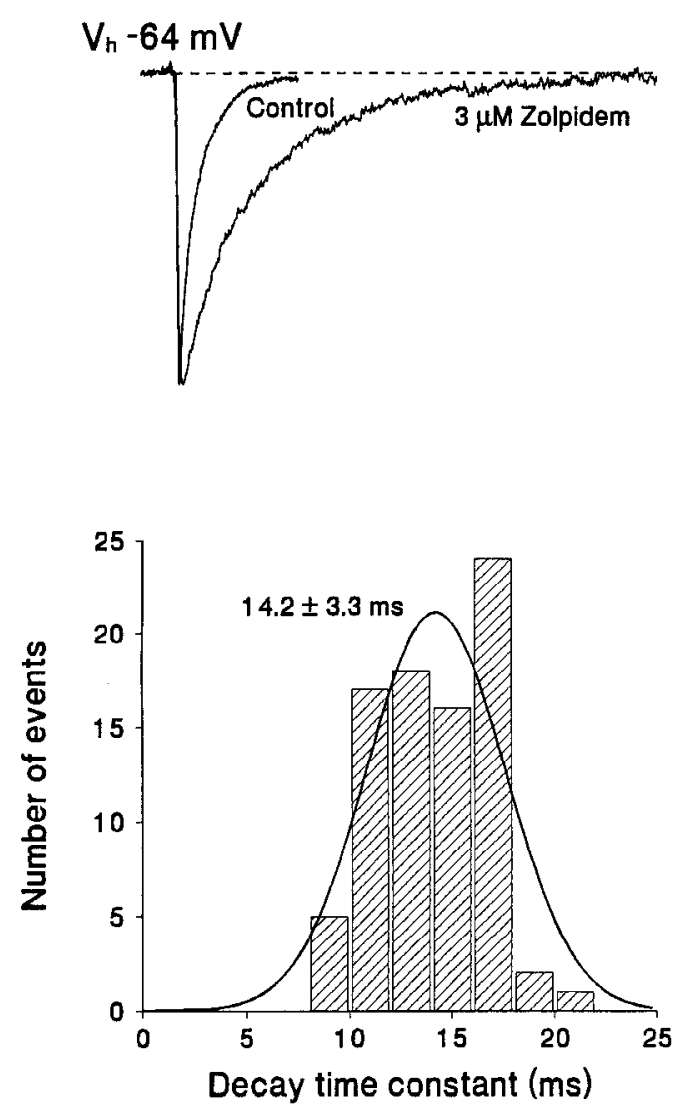

\section{Hilar Neuron}
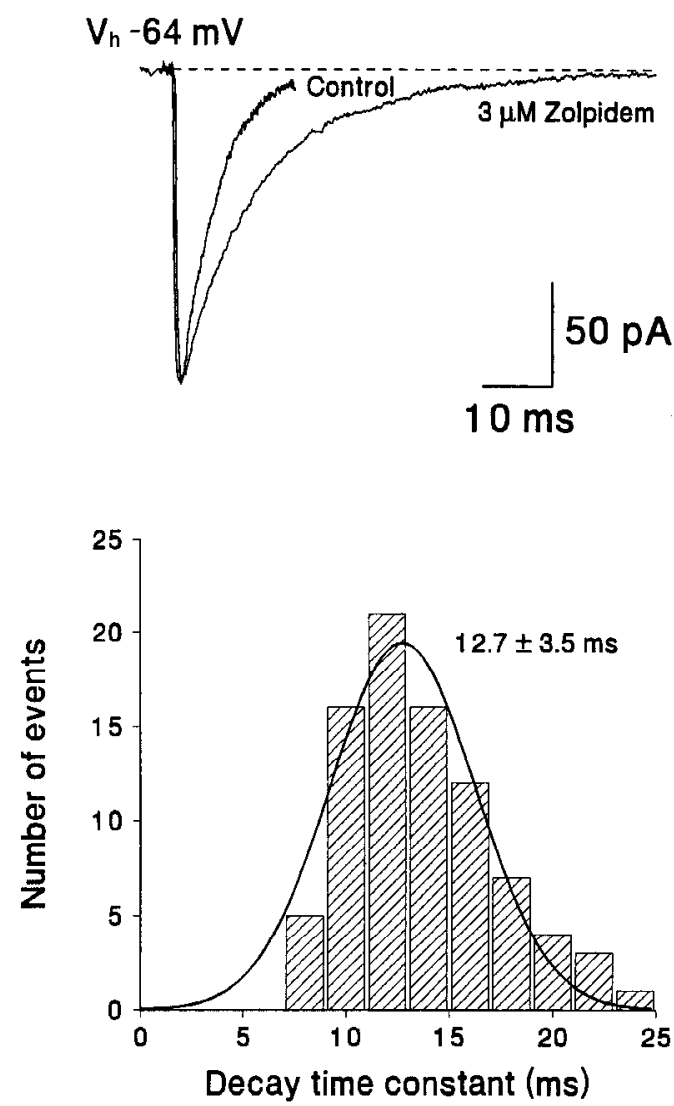

Figure 8. The effect of the benzodiazepine agonist zolpidem on the sIPSCs of GCs and HNs. $A$ and $B$, Averages of sIPSCs recorded from control GCs and HNs and from neurons recorded in the presence of $3 \mu \mathrm{M}$ zolpidem. As shown in $C$ and $D$, zolpidem increased the decay time constants of both GCs and HNs. The numbers indicate the mean and SD. Bin width $=2 \mathrm{msec}$.

cussion), the different subunit composition of $\mathrm{GABA}_{\mathrm{A}}$ receptors (Sigel et al., 1990; Verdoorn et al., 1990; Schönrock and Bormann, 1993) may also underlie or contribute to the observed differences in the properties of the sIPSCs between HNs and GCs. The in situ studies of Persohn et al. (1992) indicated a relatively weaker expression of the $\alpha 3$ and $\alpha 5$ (as well as $\delta$ ) subunits in HNs. The benzodiazepine receptor agonist zolpidem, which has higher affinity for the $\alpha 1-3$ subunits than for the $\alpha 5$ subunit of the $\mathrm{GABA}_{\mathrm{A}}$ receptor (Pritchett and Seeburg, 1990; Puia et al., 1991; Mertens et al., 1993), increased the decay time constants in both HNs and GCs (Fig. 8) at both low $(3 \mu \mathrm{M})$ and high $(30 \mu \mathrm{M})$ concentrations (mean $\tau_{\text {decay }}$ values in 3 and $30 \mathrm{M}$ zolpidem, respectively, $n=2$ at each concentration: HNs, 13 and $28 \mathrm{msec}$; GCs, 13 and $21 \mathrm{msec}$ ), suggesting that the difference between the channels is probably not due to an all-or-none presence/absence of the $\alpha 5$ subunit.

The action of $G A B A_{A}$ receptor activation on the resting membrane potential

The whole-cell patch-clamp experiments described above revealed a perpetual bombardment of the HNs' cell membrane by spontaneously released GABA and showed that the sIPSCs exhibit some significant differences from those recorded in GCs. In the next series of experiments we attempted to determine what changes, if any, GABA ${ }_{A}$ receptor activation induces in the membrane potential of HNs. This question was particularly interesting in the light of recent reports suggesting that depolarizing $\mathrm{GABA}_{\mathrm{A}}$ receptor-mediated responses, probably in conjunction with voltage-dependent currents may play an important role in the synchronization of neuronal activity in the hilus (Michelson and Wong, 1991). Because both sharp electrode and whole-cell recordings interfere with the relationship between $E_{\mathrm{Cl}}$ and the resting membrane potential (RMP), which determines whether $\mathrm{GABA}_{\mathrm{A}}$ receptor activation leads to depolarization, hyperpolarization, or no change in the RMP, we performed recordings of HNs and GCs in the cell-attached configuration in the presence of TTX (and AP5 and CNQX). The experimental paradigm is shown in Figure $9 A$. Briefly, with electrodes that contained $135 \mathrm{mM} \mathrm{K}^{+}$, which is close to that of the intracellular milieu, we formed cell-attached patches on the cell membrane and recorded from presumed $\mathrm{K}^{+}$channels that served as transmembrane voltage sensors (Zhang and Jackson, 1993). At RMP (i.e., with no current), the conductance of the $\mathrm{K}^{+}$channels varied between 25 and 90 pS (Johansson and Arrhem, 1992). Plots of voltage (holding potential of the patch from rest) versus singlechannel current revealed that the channels behaved linearly between 0 and $-80 \mathrm{mV}$ (Fig. 10A). The channels reversed at -79.8 $\pm 7.5 \mathrm{mV}$ in HNs $(n=6)$, and at $-82.5 \pm 2.7 \mathrm{mV}$ in GCs $(n$ $=3$ ) (Fig. 10A). These reversal potential values are good estimates of the unperturbed RMPs of these cells, since reasonably small differences between $\left[\mathrm{K}^{+}\right]_{\text {in }}$ and $\left[\mathrm{K}^{+}\right]_{\text {pipett }}$ would have only negligible effects. Following a period of control recording, we 


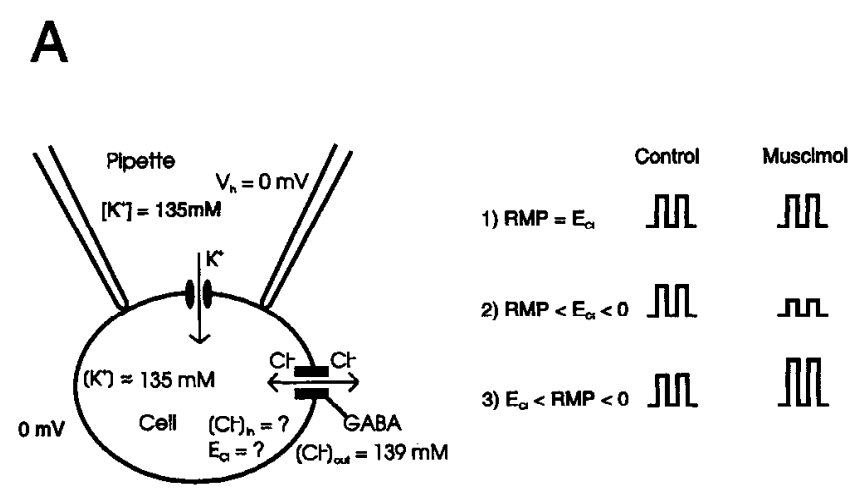

B

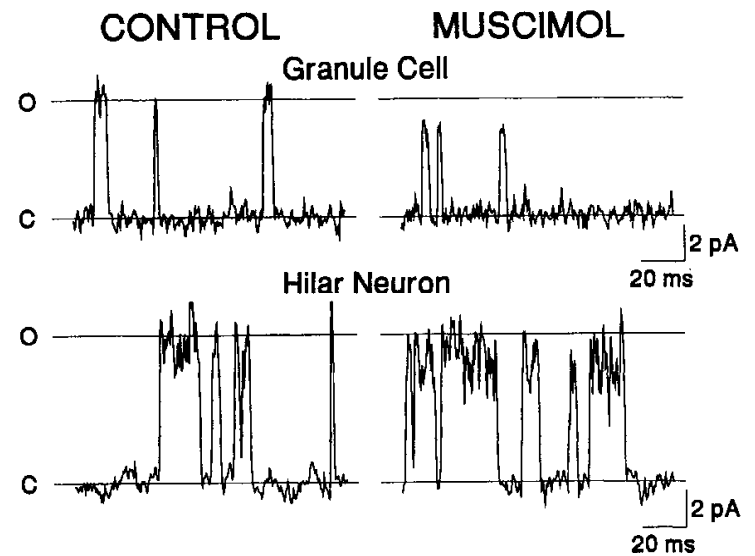

Figure 9. Cell-attached recording of $\mathrm{K}^{+}$channels on HNs and GCs and the effect of muscimol. $A$, The recording arrangement is shown schematically on the left, and the principle of the experiment is on the right. The patch containing the $\mathrm{K}^{+}$channel is kept at rest (i.e., at $0 \mathrm{mV}$ relative to $R M P$ ). Following the application of the $G_{A B A}$ receptor agonist muscimol the amplitude of the $\mathrm{K}^{+}$channel either (1) does not change [no change in the resting membrane potential $(R M P)$ ], (2) decreases (muscimol depolarizes the RMP), or (3) increases in its amplitude (muscimol hyperpolarizes the RMP). $B$, Examples of single $\mathrm{K}^{+}$ channels recorded at the RMP from GCs and HNs in control conditions and in the presence of muscimol.

switched to a solution containing the $\mathrm{GABA}_{\mathrm{A}}$ reccptor agonist muscimol $(100 \mu \mathrm{M})$ for $5 \mathrm{~min}$. The exchange time of the perfusion of muscimol was 3-4 min as assessed from whole-cell recordings. Whereas muscimol caused a reversible, relatively large $(-20 \pm 2 \% ; n=4)$ decrease in single $\mathrm{K}^{+}$channel current in GCs, HNs responded with a much smaller change, although that change, on average, was in the same direction $(-5 \pm 3 \%$; $n=5$ ) (Figs. 9B, 10B). Since the relative percentage decrease in single-channel current corresponds to an equivalent relative decrease in RMP, these results indicated that GCs responded with a rather uniform large, about $16 \mathrm{mV}$ depolarization to muscimol, whereas HNs, on average, showed a small depolarization of about $4 \mathrm{mV}$ in response to $\mathrm{GABA}_{\mathrm{A}}$ receptor activation.

\section{Discussion}

The main findings of our study can be summarized as follows: (1) HNs are subjected to tonic $\mathrm{GABA}_{\mathrm{A}}$ receptor-mediated inhibition in vitro; (2) the hilar sIPSCs, most of which result from action potential-independent release of GABA, show significant
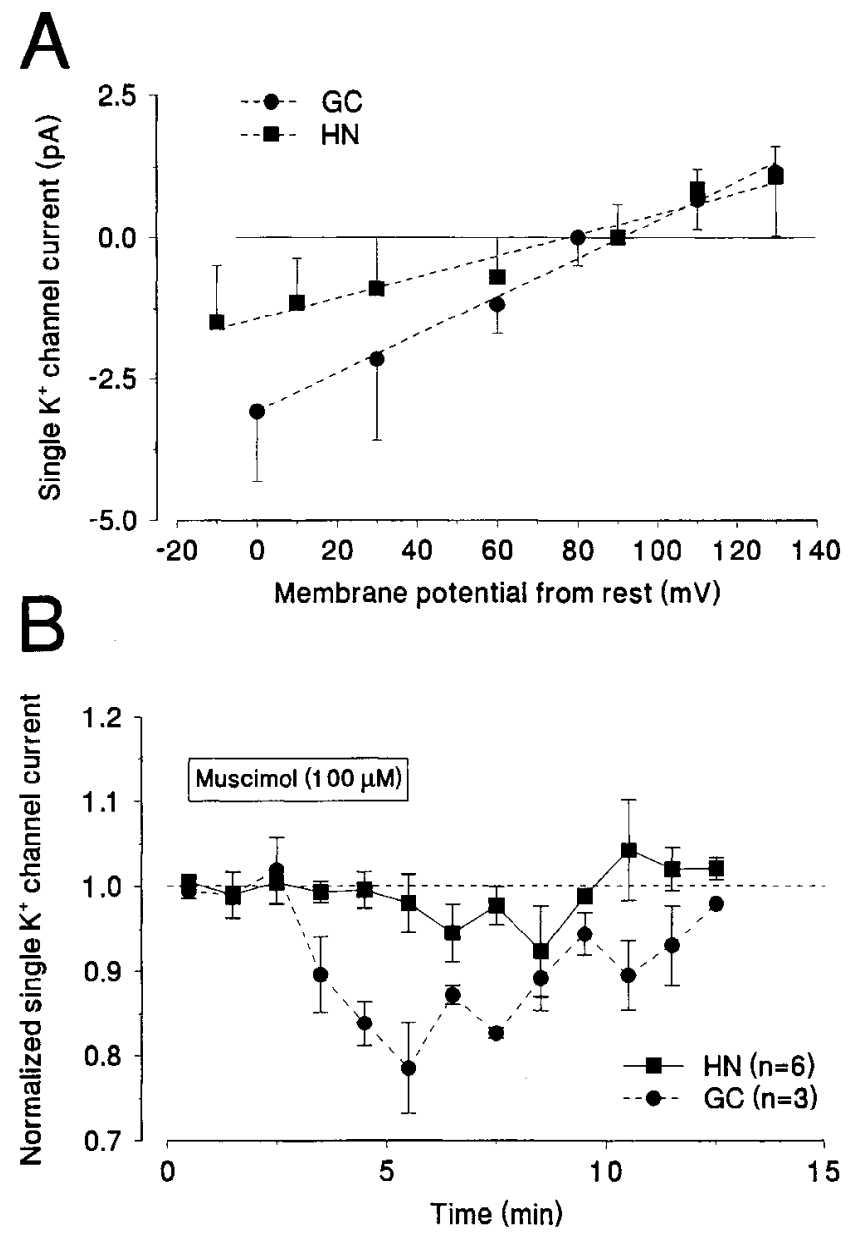

Figure 10. The RMP of HNs and GCs and the time course of action of muscimol. $A, I-V$ plot of a $\mathrm{K}^{+}$channel recorded from an $\mathrm{HN}$ and a GC. Note that between holding potentials of $0-80 \mathrm{mV}$ the plot is linear, and also that the channel reverses around $+80 \mathrm{mV}$. As recordings were done in symmetrical $\left[\mathrm{K}^{+}\right]$, the reversal potential of current flow through $\mathrm{K}^{+}$channels should be $0 \mathrm{mV}$. The $+80 \mathrm{mV}$ needed to change the RMP of the patch to the $E_{\mathrm{K}}$ indicates that the cell's true RMP was $-80 \mathrm{mV}$. The amplitude of the channel in these cases was assessed from all-points histograms, and thus the conductance of the channel $(\sim 20$ and $40 \mathrm{pS})$ is underestimated by at least $40 \%$. $B$, Time course of the reversible indirect action of muscimol on the amplitude of $\mathrm{K}^{+}$channels in GCs and HNs. GCs exhibited a relatively large decrease in the amplitude of the $\mathrm{K}^{+}$channel current in response to muscimol, indicating a depolarization of about $20 \%$ of the RMP, which amounts to approximately 16 $\mathrm{mV}$ for RMPs around $-80 \mathrm{mV}$. HNs showed a considerably smaller decrease in the amplitude of the channels, which suggests a smaller depolarization of the membrane. In no case was there a significant hyperpolarization observed.

differences in their kinetic properties with respect to those that are present in GCs; (3) different subunit compositions of GABA $A_{A}$ receptors in HNs and GC.s, in addition to the different electrotonic structure, underlie the observed differences; (4) the RMPs of $\mathrm{HNs}$ and GCs are close to $-80 \mathrm{mV}$ when glutamatergic transmission is blocked; and (5) $\mathrm{GABA}_{\mathrm{A}}$ receptor activation depolarizes the RMP strongly in GCs but does so only weakly in HNs.

Factors underlying the differences in the properties of SIPSCs from $H N s$ and $G C S$

The sIPSCs of HNs differed from those of GCs in three important aspects: (1) their rise times were longer, (2) their decay 
time constants were higher, and (3) their decay time constants were independent of membrane voltage. These differences may result from differences in $\mathrm{GABA}_{\mathrm{A}}$ receptor channels or in the elcctrotonic cable structure of the ncurons. Our data from electrotonic cable analysis indicating that the electrotonic length of HNs is about twice the electrotonic length of GCs agreed well with published values from whole-cell patch clamp studies $[L$ $=0.49$ for GCs in Staley et al. (1992), and $L=0.9$ for spiny HNs in Livsey and Vicini (1992)]. As mentioned in Materials and Methods, the voltage-clamp technique used overestimates $L$ particularly if there is severe tapering of the dendrites (Holmes and Rall, 1992). The dendrites of GCs obey the $3 / 2$ power law (Desmond and Levy, 1984), and therefore if an overestimation of $L$ occurred it was in the case of the HNs, indicating that the real difference between the $L$ values of HNs and GCs might be smaller than found. In any case, the difference in $L$ suggests that there is a possibility that the kinetic differences of sIPSCs may result from differences in the electrotonic structure and the resulting space-clamp problems in the two groups of neuron. This would be especially so if the channels generating the sIPSCs would be located preferentially on the distal dendrites of HNs, which would be very interesting in itself because it would indicate that most of the spontaneous inhibition in HNs arises from distant dendritic sites. However, there are symmetrical synapses and GABAergic terminals on the electrotonically probably close axon initial segments (Han et al., 1993), as well as on the somata and proximal dendrites (Ribak et al., 1985; Ribak and Seress 1988; C. Ribak, personal communication) of HNs (unfortunately, the quantitative spatial distribution of GABAergic terminals on the surface of the HNs is not known).

Nonstationary fluctuation analysis indicated that the number of subsynaptic receptors is similar, but a significant difference exists in the single-channel conductances of $\mathrm{GABA}_{\mathrm{A}}$ receptors in the two neurons. Although dendritic filtering would decrease the single-channel conductance estimated by nonstationary fluctuation analysis (Traynelis et al., 1993), it is unlikely that filtering alone would account for the observed differences. As mentioned above, there are numerous GABAergic synapses on electrotonically close parts of HNs. Our nonstationary fluctuation analysis focused on the fastest $10-90 \%$ rise time events in any given cell (see Materials and Methods). I'hese events are likely to have originated from electrotonically close synapses and it is difficult to imagine that such synapses are all silent; that is, they do not spontaneously release GABA. In addition, the 22 versus $28 \mathrm{pS}$ difference is larger than that expected from electrotonic filtering alone (Traynelis et al., 1993). Thus, these results are compatible with differences in the subunit composition of the GABA $\mathrm{A}_{\mathrm{A}}$ receptor channels between HNs and GCs. Although molecular biological studies (Persohn et al., 1992; Wisden et al., 1992) indicated that the $\alpha 5$ subunit (which is present almost exclusively in the hippocampus) was strongly expressed in GCs and below detectable levels in HNs, zolpidem did not differentiate in an all-or-none manner between the GA$B A_{A}$ receptors of $H N s$ and $G C s$. This suggests that in native $\mathrm{GABA}_{\mathrm{A}}$ receptors the $\alpha 5$ subunit is mixed together with other subunits to constitute a physiologically relevant receptor population at the GABAergic synapses on GCs. In any case, the differences in mRNA expression described by the study of Persohn et al. (1992) included, in addition to $\alpha 5$ subunit (where the strongest difference was noted between HNs and GCs), also $\alpha 3$ and $\delta$ ( $\alpha 4$ was not studied), and thus these molecular biology findings in general are consistent with different kinetics and single-channel conductance suggested by our nonstationary fluctuation analysis.

\section{Origin of $G A B$ Aergic inhibition in the hilus}

The hilus has a diverse intrinsic GABAergic circuitry (Seress and Ribak, 1983; Somogyi et al., 1984; Ribak et al., 1985; Misgeld and Frotscher, 1986; Kosaka et al., 1988; Ribak and Seress, 1988; Müller and Misgeld, 1990; Han et al., 1993) and it also receives several extrinsic GABAergic inputs. The latter include fibers from basket cells of the GC layer of the dentate gyrus (Han et al., 1993), from the contralateral hilus (Ribak et al., 1986), and from the medial septum-vertical limb of the diagonal band of Broca complex (Freund and Antal, 1988). Clearly, in the slice many axons are separated from their cell bodies. The integrity of presynaptic fibers was shown to influence the rate of action potential-independent excitatory neurotransmitter release (Staley and Mody, 1991). If this also applies to GABA release, then the relatively high frequency of the TTX-resistant sIPSCs in HNs may stem from a portion of hilar GABAergic axons that are not scparated from their cell bodies. On the other hand, it has been suggested, on the basis of the relative ease with which IPSPs can be evoked in mossy cells in vivo versus in vitro (both with sharp electrodes; see introductory remarks), that the parent cell bodies of the GABAergic neurons forming synapses on a given HN might be spatially distant from it and thus not present in the same slice (Soltesz et al., 1993). This is clearly the case for the inputs from the contralateral hilus and the septum. It also seems likely that the ipsilateral axonal tree of the dentate GABAergic cells is rather extensive (Amaral and Witter, 1989; Halasy and Somogyi, 1993; Han et al., 1993). Thus, there may be a large number of GABAergic terminals without their parent cell bodies in the slice. The finding that TTX caused only a small reduction in the frequency of sIPSCs in HNs is certainly consistent with this hypothesis.

\section{The relationship between $\mathrm{E}_{C l}$ and the resting membrane potential}

The relationship between $E_{\mathrm{C}}$ and the RMP determines whether $\mathrm{GABA}_{\mathrm{A}}$ receptor activation leads to depolarization, hyperpolarization, or no change in the RMP. However, the nature of this relationship has remained elusive partly because the intracellular $\mathrm{Cl}^{-}$ion concentration is difficult to assess. In addition, there are problems associated with the exact measurement of the RMP of a cell, because the process of experimental observation itself may cause changes in the object of observation. For example, the penetration of neurons with sharp microelectrodes interferes with the physiological state of the cell (Staley et al., 1992). On the other hand, the RMP measured after breakthrough in the whole-cell configuration will be influenced by the filling solution of the whole-cell patch electrode.

Cell-attached recordings, however, do not rupture the cell membrane and therefore lead to no disturbances in the physiological characteristics of neurons. In this recording configuration, $\mathrm{K}^{+}$channels can serve as transmembrane voltage sensors. Thus, cell-attached recordings of single $\mathrm{K}^{+}$channels can be used not only to measure the RMPs of neurons without damaging the cells, but in addition, such recordings before and after the application of $\mathrm{GABA}_{\mathrm{A}}$ receptor agonists offer a nonintrusive way of establishing the direction of the membranc potential changes in response to the activation of $\mathrm{GABA}_{\mathrm{A}}$ receptors (Zhang and Jackson, 1993).

Our results with the cell-attached patches showed that the 
RMPs of HNs and GCs are close to $-80 \mathrm{mV}$, at least under our conditions when all ionotropic glutamatergic excitation is blocked. Whether this is so in vivo we cannot know for sure. Data from extracellular (Mizumori et al., 1989; Jung and McNaughton, 1993) and intracellular (I. Soltesz and M. Deschênes, unpublished observations) in vivo electrophysiological recordings of GCs, as well as data from in vivo intracellular recordings of mossy HNs (Soltesz et al., 1993), indicate that these neurons reach firing threshold only rarely during theta oscillations, suggesting that their "resting" membrane potential is rather hyperpolarized in vivo as well. Interestingly, in spite of the similar RMPs, GABA $A_{A}$ receptor activation leads to large depolarizations in GCs and only to small ones in HNs. This may indicate that $E_{\mathrm{Cl}}$ in GCs might be at a more depolarized potential than it is in HNs.

In the light of recent studies suggesting that depolarizing GA$\mathrm{BA}_{\mathrm{A}}$ responses underlie the synchronization of neuronal electrical activity in the hilus, it is especially interesting to ask whether $\mathrm{GABA}_{\mathrm{A}}$ receptor-mediated depolarizations have the magnitude to serve as means of synchronization. Although Michelson and Wong (1991) interpreted their findings as indicating the involvement of depolarizing GABA responses in the synchronization of $G A B$ Aergic cells, the idea that synchronization may be achieved via depolarizing $G A B A$ responses would still be interesting even if the majority of the participating HNs were non-GABAergic and would be driven to oscillate by the depolarizing responses originating from GABAergic neurons that themselves would be synchronized by some mechanism, perhaps via gap junctions (Michelson and Wong, 1992). Our data suggest that the depolarizing GABA responses by themselves in HNs would not be of sufficient amplitude to achieve synchronous firing because the RMP is close to $E_{\mathrm{Cl}}$ and is rather hyperpolarized and thus most likely well below firing threshold in these neurons. However, these small depolarizing $\mathrm{GABA}_{\mathrm{A}}$ responses may contribute to the synchronization of subthreshold events in HNs, and thus appear as extracellular potentials on the EEG electrodes. In addition, specific voltage-dependent conductances intrinsic to the cells may amplify these small depolarizations such that the membrane potential reaches the threshold for firing.

\section{Physiological significance}

The discovery of tonic GABAergic activity in HNs adds a new dimension to our thinking about the dentate gyrus. Importantly, these neurons are subjected to perpetual bombardment of the cell membranes by both glutamate and GABA. The effect of this continuous spontaneous GABAergic activity is likely to be a strong shunting effect, irrespective of the fact that $\mathrm{GABA}_{\mathrm{A}}$ receptor activation leads to depolarizing responses in $\mathrm{HNs}$ and GCs (Staley and Mody, 1992). During physiological rhythms like the theta rhythm, extra- and intracellularly recorded presumed GABAergic cells fire clusters of action potentials phaselocked to the theta rhythm (Buzsáki and Eidelberg, 1983; Buzsáki et al., 1983; Fox et al., 1986; Soltesz and Deschênes, 1993). Thus; it is likely that the in vivo activation of $\mathrm{GABA}_{\mathrm{A}}$ receptors on HNs takes place in a discontinuous manner in time with some rhythmicity, on the background of tonic inhibition resulting from the spontaneous (i.e., action potential-independent) release of GABA. Such clustering of the IPSCs will bring the membrane potentials of $\mathrm{HNs}$ and $\mathrm{GCs}$ close to $E_{\mathrm{Cl}}$ and at the same time shunt the excitatory influence coming from glutamatergic neurons. Synchronization of this temporal patterning of inhibitory activity in a large number of neurons, in turn, would result in the appearance of oscillatory waves such as the theta rhythm or the fast oscillations of the dentate gyrus.

Finally, these results demonstrate that the underlying reason for vulnerability of HNs to excitotoxic insults (Mouritzen-Dam, 1980; Sloviter, 1983, 1987, 1989, 1991; Babb et al., 1984; Benveniste and Diemer, 1988; Sutula et al., 1992) is not a general lack of inhibition. Our data suggest that the slower time course of the GABAergic IPSCs in HNs would be favorable for the temporal summation of the individual events that might offset the smaller conductance of the hilar $\mathrm{GABA}_{\mathrm{A}}$ channel. Furthermore, the fact that benzodiazepines like zolpidem prolong the IPSCs in HNs as well may suggest new ways of protecting these cells against overexcitation.

\section{References}

Amaral DG (1978) A Golgi study of the cell types in the hilar region of the hippocampus in the rat. J Comp Neurol 182:851-914.

Amaral DG, Witter MP (1989) The three-dimensional organization of the hippocampal formation: a review of anatomical data. Neuroscience 31:571-591.

Artemenko DP (1972) Role of hippocampal neurons in theta-wave generation. Neurofiziologia 4:409-415.

Babb TL, Lieb JP, Brown WJ, Pretorius J, Crandall PH (1984) Distribution of hippocampal cell density and hyperexcitability in the epileptic human hippocampal formation. Epilepsia 25:721-728.

Benveniste H, Diemer NH (1988) Early postischemic ${ }^{45} \mathrm{Ca}$ accumulation in the rat dentate hilus. J Cereb Blood Flow Metab 8:713-719.

Blanton MG, LoTurco JL, Kriegstein AR (1989) Whole-cell recording from neurons in slices of reptilian and mammalian cortex. J Neurosci Methods 30:203-210.

Buzsáki G, Eidelberg E (1983) Phase relations of hippocampal projection cells and interneurons to theta activity in the anesthetized rat. Brain Res 266:334-339.

Buzsáki G, Leung LS, Vanderwolf CH (1983) Cellular bases of hippocampal EEG in the behaving rat. Brain Res Rev 6:139-171.

De Koninck Y, Otis TS, Mody I (1992) Modulation of synaptic GABA currents in brain slices: non-stationary fluctuation analysis. Soc Neurosci Abstr 18:401.

Desmond NL, Levy WB (1984) Dendritic caliber and the $3 / 2$ power relationship of dentate granule cells. J Comp Neurol 227:589-596.

Fox SE (1989) Membrane potential and impedance changes in hippocampal pyramidal cells during theta rhythm. Exp Brain Res 77 : 283-294.

Fox SE, Wolfson S, Ranck JB Jr (1986) Hippocampal theta rhythm and the firing of neurons in walking and urethane anesthetized rats. Exp Brain Res 62:495-508.

Freund TF, Antal M (1988) GABA-containing neurons in the septum control inhibitory interneurons in the hippocampus. Nature (Lond) 336:170-173.

Frotscher M, Seress L, Schwerdtfeger WK, Buhl E (1991) The mossy cells of the fascia dentata: a comparative study of their fine structure and synaptic connections in rodents and primates. J Comp Neurol 312:145-163.

Halasy K, Somogyi P (1993) Subdivisions in the multiple GABAergic innervation of granule cells in the dentate gyrus of the rat hippocampus. Eur J Neurosci 5:411-429.

Han ZS, Buhl EH, Lorinczi Z, Somogyi P (1993) A high degree of spatial selectivity in the axonal and dendritic domains of physiologically identified local-circuit neurones in the dentate gyrus of the rat hippocampus. Eur J Neurosci 5:395-410.

Holmes WR, Rall W (1992) Electrotonic length estimates in neurons with dendritic tapering or somatic shunt. J Neurophysiol 68:14211437.

Horikawa K, Armstrong WE (1988) A versatile means of intracellular labeling: injection of biocytin and its detection with avidin conjugates. J Neurosci Methods 25:1-11.

Jackson MB (1992) Cable analysis with the whole-cell patch clamp. Theory and experiment. Biophys J 61:756-766.

Johansson S, Århem P (1992) Single K+ ${ }^{+}$-channel currents under steady- 
state potential conditions in small hippocampal neurons. Brain Res 596:133-141.

Jung MW, McNaughton BL (1993) Spatial selectivity of unit activity in the hippocampal granular layer. Hippocampus 3:165-182.

Kosaka T, Wu J-Y, Benoit S (1988) GABAergic neurons containing somatostatin-like immunoreactivity in the rat hippocampus and dentate gyrus. Exp Brain Res 71:388-398.

Lambert JDC, Jones RSG (1990) A reevaluation of excitatory aminoacid mediated synaptic transmission in the rat dentate gyrus. $J$ Neurophysiol 64:119-132.

Leung LS, Yim CY (1986) Intracellular records of theta rhythm in hippocampal CA1 cells of the rat. Brain Res 367:323-327.

Livsey CT, Vicini S (1992) Slower spontaneous excitatory postsynaptic currents in spiny versus aspiny hilar neurons. Neuron 8:745-755.

Major G (1993) Solutions for transients in arbitrarily branching cables. III. Voltage clamp problems. Biophys J 65:469-491.

Mertens S, Benke D, Mohler H (1993) $\mathrm{GABA}_{\mathrm{A}}$ receptor populations with novel subunit combinations and drug binding profiles identified in brain by alpha 5- and delta-subunit-specific immunopurification. J Biol Chem 268:5965-5973.

Michelson HB, Wong RKS (1991) Excitatory synaptic responses mediated by $\mathrm{GABA}_{\mathrm{A}}$ receptors in the hippocampus. Science 253:14201423.

Michelson HB, Wong RKS (1992) Excitatory synaptic coupling between GABAergic interneurons in the hippocampus. Soc Neurosci Abstr 22:1240.

Miller R (1991) Cortico-hippocampal interplay. Berlin: Springer

Misgeld U, Frotscher M (1986) Postsynaptic-GABAergic inhibition of non-pyramidal neurons in the guinea-pig hippocampus. Neuroscience 19:193-206.

Mizumori SJY, McNaughton BL, Barnes CA (1989) A comparison of supramammillary and medial septal influences on hippocampal field potentials and single unit activity. J Neurophysiol 61:15-31.

Mouritzen-Dam A (1980) Epilepsy and neuron loss in the hippocampus. Epilepsia 21:617-629.

Müller W, Misgeld U (1990) Inhibitory role of dentate hilar neurons in guinea pig hippocampal slice. J Neurophysiol 64:46-56.

Otis TS, Mody I (1992) Modulation of decay kinetics and frequency of GABA receptor-mediated spontaneous inhibitory postsynaptic currents in hippocampal neurons. Neuroscience 49:13-32.

Otis TS, Staley KJ, Mody I (1991) Perpetual inhibitory activity in mammalian brain slices generated by spontaneous GABA release. Brain Res 545:142-150.

Paxinos G, Watson C (1986) The rat brain in stereotaxic coordinates. Marrickville, Australia: Academic.

Persohn E, Malherbe P, Richards JG (1992) Comparative neuroanatomy of cloned $\mathrm{GABA}_{\mathrm{A}}$ receptor subunits in the rat CNS. J Comp Neurol 326:193-216.

Pritchett DB, Seeburg PH (1990) Gamma-aminobutyric acid A receptor alpha 5-subunit creates novel type II benzodiazepine receptor pharmacology. J Neurochem 54:1802-1804.

Puia G, Vicini S, Seeburg PH, Costa E (1991) Influence of recombinant gamma-aminobutyric acid-A receptor subunit composition on the action of allosteric modulators of gamma-aminobutyric acid-gated $\mathrm{Cl}^{-}$currents. Mol Pharmacol 39:691-696.

Rall W (1969) Time constants and electrotonic length of membrane cylinders and neurons. Biophys J 9:1483-1508.

Ribak CE, Seress L (1988) A Golgi-electron microscopy study of fusiform neurons in the hilar region of the dentate gyrus. J Comp Neurol 271:67-78

Ribak CE, Vaughn JE, Saito K (1978) Immunocytochemical localization of glutamic acid decarboxylase in neuronal somata following colchicine inhibition of axonal transport. Brain Res 140:315-332.

Ribak CE, Seress L, Amaral DG (1985) The development, ultrastructure and synaptic connections of the mossy cells of the dentate gyrus. J Neurocytol 14:835-857

Ribak CE, Seress L, Peterson GM, Seroogy KB, Fallon JH, Schmued LC (1986) A GABAergic inhibitory component within the hippocampal commissural pathway. J Neurosci 6:3492-3498.

Robinson HP, Sahara Y, Kawai N (1991) Nonstationary fluctuation analysis and direct resolution of single channel currents at postsynaptic sites. Biophys J 59:295-304.

Scharfman HE (1991) Dentate hilar cells with dendrites in the molecular layer have lower thresholds for synaptic activation by perforant path than granule cells. J Neurosci 11:1660-1673.
Scharfman HE (1992) Blockade of excitation reveals inhibition of dentate spiny hilar neurons recorded in rat hippocampal slices. J Neurophysiol 68:978-984

Scharfman HE, Schwartzkroin PA (1988) Electrophysiology of morphologically identified mossy cells of the dentate hilus recorded in guinea pig hippocampal slices. J Neurosci 8:3812-3821.

Scharfman HF, Schwartzkroin PA (1990) Responses of cells of the rat fascia dentata to prolonged stimulation of the perforant path: sensitivity of hilar cells and changes in granule cell excitability. Neuroscience 35:491-504.

Schönrock B, Bormann J (1993) Functional heterogeneity of hippo-

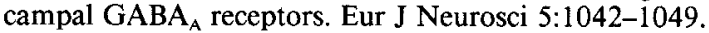

Seress L, Ribak CE (1983) GABAergic cells in the dentate gyrus appear to be local circuit and projection neurons. Exp Brain Res 50:173182.

Sigel E, Baur K, Trube G, Mohler H, Malherbe P (1990) The effect of subunit composition of rat brain $\mathrm{GABA}_{\mathrm{A}}$ receptors on channel function. Neuron 5:703-711.

Sigworth FJ (1980) The conductance of sodium channels under conditions of reduced current at the node of Ranvier. J Physiol (Lond) 307:97-129.

Sigworth FJ (1981) Interpreting power spectra from nonstationary membrane current fluctuations. Biophys J 35:289-300.

Sloviter RS (1983) "Epileptic" brain damage in rats induced by sustained electrical stimulation of the perforant path. I. Acute electrophysiological and light microscopical studies. Brain Res Bull 10:675697.

Sloviter RS (1987) Decreased hippocampal inhibition and a selective loss of interneurons in experimental epilepsy. Science 235:73-76.

Sloviter RS (1989) Calcium binding protein (calbindin $D_{28} K$ ) and parvalbumin immunocytochemistry: location in the rat hippocampus with specific reference to selective vulnerability of hippocampal neurons to seizure activity. J Comp Neurol 280:183-196.

Sloviter RS (1991) Permanently altered hippocampal structure, excitability, and inhibition after experimental status epilepticus in the rat: the "dormant basket cell" hypothesis and its possible relevance to temporal lobe epilepsy. Hippocampus 1:41-66.

Soltesz I, Deschênes M (1993) Low- and high-frequency membrane potential oscillations during theta activity in $\mathrm{CA} 1$ and $\mathrm{CA} 3$ pyramidal neurons of the rat hippocampus under ketamine-xylazine anesthesia. J Neurophysiol 70:97-116.

Soltesz I, Mody I (1993) Differences between spontaneous inhibitory postsynaptic currents (sIPSCs) recorded in granule cells and hilar neurons of the dentate gyrus. Soc Neurosci Abstr 19:1521.

Soltesz I, Bourassa J, Deschênes M (1993) The behavior of mossy cells of the rat dentate gyrus during theta oscillations in vivo. Neuroscience, in press.

Somogyi P, Hodgson AJ, Smith AD, Nunzi MG, Gorio A, Wu J-Y (1984) Different populations of GABAergic neurons in the visual cortex and hippocampus of cat contain somatostatin- or cholecystokinin-immunoreactive material. J Neurosci 4:2590-2603.

Spruston N, Johnston D (1992) Perforated patch-clamp analysis of the passive membrane properties of three classes of hippocampal neurons. J Neurophysiol 67:508-529.

Spruston N, Jaffe DB, Williams SH, Johnston D (1993) Voltage- and space-clamp errors associated with the measurement of electrotonically remote synaptic events. J Neurophysiol 70:781-802.

Staley KJ, Mody I (1991) Integrity of perforant path fibers and the frequency of action potential independent excitatory and inhibitory synaptic events in dentate gyrus granule cells. Synapse 9:219-224.

Staley KJ, Mody I (1992) Shunting of excitatory input to dentate gyrus granule cells by a depolarizing $\mathrm{GABA}_{\mathrm{A}}$ receptor-mediated postsynaptic conductance. J Neurophysiol 68:197-212.

Staley KJ, Otis TS, Mody I (1992) Membrane properties of dentate gyrus granule cells: comparison of sharp microelectrode and wholecell recordings. J Neurophysiol 67:1346-1358.

Strowbridge BW, Buckmaster PS, Schwartzkroin PA (1992) Potentiation of spontaneous synaptic activity in rat mossy cells. Neurosci Lett 142:205-210.

Sutula TP, Cavazos J, Golarai G (1992) Alteration of long-lasting structural and functional effects of kainic acid in the hippocampus by brief treatment with phenobarbital. J Neurosci 12:4173-4187.

Traynelis SF, Silver RA, Cull-Candy SG (1991) Non-stationary current variance analysis of glutamate receptor-mediated EPSCs at the mossy fiber-granule cell synapse. Soc Neurosci Abstr 17:1332. 
Traynelis SF, Silver RA, Cull-Candy SG (1993) Estimated conductance of glutamate receptor channels activated during EPSPs at the cerebellar mossy fiber-granule cell synapse. Neuron 11:279-289.

Verdoorn TA, Draguhn A, Ymer S, Seeburg PH, Sakmann B (1990) Functional properties of recombinant rat GABA $_{A}$ receptors depend upon subunit composition. Neuron 4:919-928.
Wisden W, Laurie DJ, Monyer H, Seeburg PH (1992) The distribution of $13 \mathrm{GABA}_{\mathrm{A}}$ receptor subunit mRNAs in the rat brain. I. Telencephalon, diencephalon, mesencephalon. J Neuroscience 12:10401062.

Zhang SJ, Jackson MB (1993) GABA-activated chloride channels in secretory nerve endings. Science 259:531-534. 